\title{
Inhibition of Growth of Aspergillus flavus and Fungal $\alpha$-Amylases by a Lectin-Like Protein from Lablab purpureus
}

\author{
A. M. Fakhoury and C. P. Woloshuk \\ Department of Botany and Plant Pathology, Purdue University, West Lafayette, IN 47907, U.S.A. \\ Submitted 17 January 2001; Accepted 4 April 2001.
}

\begin{abstract}
Aspergillus flavus is a fungal pathogen of maize causing an important ear rot disease when plants are exposed to drought and heat stress. Associated with the disease is the production of aflatoxins, which are a series of structurally related mycotoxins known to be carcinogenic. Previous research has suggested that the $\alpha$-amylase of $A$. flavus promotes aflatoxin production in the endosperm of infected maize kernels. We report here the isolation and characterization of a 36-kDa $\alpha$-amylase inhibitor from Lablab purpureus (AILP). AILP inhibited the $\alpha$-amylases from several fungi but had little effect on those from animal and plant sources. The protein inhibited conidial germination and hyphal growth of $A$. flavus. The amino acid sequence indicated that AILP is similar to lectin members of a lectin-arcelin- $\alpha$-amylase inhibitor family described in common bean and shown to be a component of plant resistance to insect pests. AILP also agglutinated papain-treated red blood cells from human and rabbit. These data indicate that AILP represents a novel variant in the lectin-arcelin- $\alpha$-amylase inhibitor family of proteins having lectin-like and $\alpha$-amylase inhibitory activity.
\end{abstract}

Aspergillus flavus produces a group of structurally related metabolites known as aflatoxins, which are potent liver toxins and carcinogens. Aflatoxin contamination occurs in several important crops such as maize, peanuts, cotton, and tree nuts. Because of concern over the impact aflatoxin may have on human health, the level of aflatoxin in food is regulated strictly by governmental agencies worldwide.

In maize, aflatoxin production is associated with an ear rot disease caused by A. flavus. The disease and aflatoxin contamination are especially severe when maize is stressed by drought, high temperature, and insect damage. Controlling the disease by use of resistant hybrids has been problematic because the year-to-year variability in disease development and aflatoxin contamination confounds the detection and incorporation of resistant traits. Despite the difficulties, resistance has been established in several inbred lines such as Tex6 and Mp420 and appears to involve several genetic loci (Campbell and White 1995a; Campbell and White 1995b). The resistant phenotype has been attributed to intrinsic properties, including

Corresponding author: C. Woloshuk; Telephone: +1-765-494-3450; Fax: +1-765-494-0363, E-mail: woloshuk@btny.purdue.edu the waxes and thickness of the pericarp (Guo et al. 1995; Russin et al. 1997). Several proteins in the kernel also correlate with the resistant phenotype. Comparing extracted kernel proteins from resistant (GT-MAS:gk, Mp420) and susceptible (Pioneer Brand 3154, Deltapine Brand G-4666) genotypes, Guo et al. $(1997 ; 1998)$ identified four protein bands on sodium dodecyl sulfate-polyacrylamide gel electrophoresis (SDS-PAGE) gels that were more abundant or present exclusively in the resistant genotypes. One protein band was identified as a putative $18-\mathrm{kDa}$ ribosome-inactivating protein. Huang et al. (1997) showed that kernels of Tex6 contain a 28$\mathrm{kDa}$ protein that inhibits growth of $A$. flavus and a $100-\mathrm{kDa}$ protein that inhibits aflatoxin biosynthesis, without affecting fungal growth. Their data suggest that the $28-\mathrm{kDa}$ protein is zeamatin, a thaumatin-like protein belonging to the PR5 group of pathogen-related proteins (Huang et al. 1997). Chen et al. (1998) identified a $14-\mathrm{kDa}$ protein comprising $19 \%$ of the total protein content in GT-MAS:gk kernels and other resistant maize genotypes. In contrast, susceptible genotypes contain little of the protein. The $14-\mathrm{kDa}$ protein was a trypsin inhibitor that also inhibited conidial germination and hyphal growth of A. flavus (Chen et al. 1999a). Upon further characterization, the protein was found to inhibit the $\alpha$-amylase from $A$. flavus but not from porcine pancreas (Chen et al. 1999b; Fakhoury and Woloshuk 1999).

Previous work in our laboratory focused on the identification of molecules from maize kernels associated with kernel colonization and aflatoxin production. An aflatoxin-inducing activity was identified in extracts from kernels colonized by A. flavus and was determined to be glucose, maltose, and maltotriose (Woloshuk et al. 1997). The metabolites were hypothesized to be products of starch degradation by an extracellular $\alpha$-amylase $(\alpha-1,4$-glucanhydrolase, EC 3.2.1.1) of $A$. flavus. A strain of $A$. flavus with a disrupted $\alpha$-amylase gene (amyl) grew on starch and degermed kernels but failed to produce aflatoxin (Fakhoury and Woloshuk 1999). The strain also had difficulty reaching the germ tissue when inoculated to endosperm-wounded kernels. In light of these data and the fact that several resistant maize genotypes contain the 14-kDa trypsin- $\alpha$-amylase inhibitor, we screened protein extracts from over 200 different plant species for inhibitors of the $\alpha$ amylase from A. flavus. Here, we describe the isolation and characterization of a $36-\mathrm{kDa}$ protein from the legume Lablab purpureus (Dolichos lablab) that inhibits $\alpha$-amylase and the growth of A. flavus. 


\section{RESULTS}

\section{Purification of AILP.}

In a preliminary screen of 200 protein extracts from different plant species, an inhibitor of the $\alpha$-amylase from A. flavus was detected in extracts from $L$. purpureus. In scaled-up extractions, the inhibitor activity was masked by endogenous $\alpha$ amylase (data not shown). Removal of this endogenous activity was accomplished by selectively binding the $\alpha$-amylase inhibitor to a chitin affinity column. From $5 \mathrm{~g}$ of seeds, $170 \mathrm{U}$ of inhibitor activity were recovered from the chitin affinity column (Table 1). As revealed by SDS-PAGE analysis, the chitin column chromatography also enriched a $36-\mathrm{kDa}$ protein (Fig. 1). This protein fraction was applied to an anion exchange column, and the $\alpha$-amylase inhibitor was eluted as a single peak containing $250 \mathrm{U}$ of $\alpha$-amylase inhibitor per milligram of protein. SDS-PAGE analysis indicated that this fraction contained a single $36-\mathrm{kDa}$ protein (Fig. 1). When the protein band was eluted and renatured from the electrophoresis gel, $60 \%$ of the $\alpha$-amylase inhibitor activity was recovered. The 36-kDa protein was named "AILP."

Amino acid sequence analysis of the $\mathrm{N}$ terminus and two tryptic fragments from AILP revealed 68 to $75 \%$ identity with the phytohemagglutinin-L from Phaseolus acutifolius and 45 to $63 \%$ identity with an $\alpha$-amylase inhibitor-like protein from Phaseolus lunatus (Fig. 2).

\section{pH optimum.}

With starch as a substrate, the $\alpha$-amylase from A. flavus was active from $\mathrm{pH} 5$ to 10 , with maximum activity at $\mathrm{pH} 8$. AILP inhibited $\alpha$-amylase between pH 5 to 8, with a maximum inhibition at $\mathrm{pH} 7$ (Fig. 3).

\section{AILP is a competitive inhibitor to the $\alpha$-amylase from A. flavus.}

Increasing the concentrations of starch to $\alpha$-amylase of $A$. flavus increased the reaction velocity to a maximum of 1.4 $\mu$ moles of maltose released per min (Fig. 4). The addition of AILP greatly reduced the reaction velocity. In the presence of higher amounts of starch, however, inhibition by AILP decreased and the reaction velocity approached the maximum observed without AILP. Lineweaver-Burk plot analysis indicated that the addition of AILP increased the $\mathrm{K}_{\mathrm{M}}$ value by $900 \%$, whereas the $\mathrm{V}_{\max }$ was reduced by $27 \%$ (Fig. 4). These data indicate that AILP is a competitive inhibitor with starch for the $\alpha$-amylase from $A$. flavus.

\section{AILP is not a trypsin inhibitor.}

AILP has no inhibitory activity toward porcine pancreas trypsin. In contrast, a trypsin inhibitor from soybean reduced trypsin activity by $97 \%$ (data not shown).

Table 1. Purification of $\alpha$-amylase inhibitor from Lablab purpureus (AILP) from the seeds of L. purpureus ${ }^{\mathrm{a}}$

\begin{tabular}{lccc}
\hline & Protein (mg) & Units of AILP $^{\mathbf{b}}$ & Specific activity $^{\mathbf{c}}$ \\
\hline Homogenate & 1,200 & $0^{\mathrm{d}}$ & 0 \\
$\left(\mathrm{NH}_{4}\right)_{2} \mathrm{SO}_{4}$ & 40 & 0 & 0 \\
Chitin & 10 & 170 & 17 \\
FPLC & 0.6 & 150 & 250 \\
\hline
\end{tabular}

a AILP was isolated following a four-step purification process.

${ }^{\mathrm{b}}$ One unit of inhibitor reduced the activity of $1 \mathrm{U}$ of $\alpha$-amylase by $50 \%$.

${ }^{\mathrm{c}}$ Units per milligram of protein.

${ }^{\mathrm{d}}$ No inhibitory activity was detected.

\section{AILP has lectin activity.}

AILP did not agglutinate nonpapain-treated red blood cells. Papain-treated red blood cells from human and rabbit agglutinated in the presence of AILP within $30 \mathrm{~min}$. AILP, however, did not agglutinate papain-treated red blood cells from horse and bovine, whereas a soybean lectin agglutinated all four sources of red blood cells.

\section{AILP inhibits fungal growth.}

When conidia of A. flavus were incubated with 280 pmoles of AILP in a total volume of $100 \mu$, germination was reduced by $84 \%$ compared with conidia treated with boiled AILP (Table 2). Of the conidia that germinated, AILP reduced hyphal elongation by $67 \%$. No lysis or agglutination of the conidia or hyphae was observed.

\section{AILP inhibits $\alpha$-amylases from different sources.}

In order to test the effect of AILP on $\alpha$-amylases from other sources, $10 \mathrm{U}$ of $\alpha$-amylases were incubated with and without 45 pmoles of AILP prior to the addition of the substrate $p$ nitrophenyl- $\alpha$-D-maltoside. AILP inhibited the $\alpha$-amylases from Magnaporthe grisea, A. flavus, and Helminthosporium victoriae by over $65 \%$ (Table 3 ). The $\alpha$-amylases from Colletotrichum graminicola, Fusarium graminearum, and Fusarium verticillioides were inhibited by 30,18 , and $15 \%$, respectively. AILP also inhibited the $\alpha$-amylase from Bacillus subtilis by $41 \%$. In contrast, AILP inhibited the $\alpha$-amylases from maize, porcine pancreas, and human saliva only by 5,6 , and $11 \%$, respectively.

\section{DISCUSSION}

$\alpha$-Amylases play an important role in a number of plantmicrobe interactions. Amylases are required by the pathogen Pythium pleroticum to rot rhizomes of ginger, especially during the early stages of pathogenesis (Dohroo et al. 1987). A wilt on cauliflower caused by Fusarium solani also has been correlated with the production of $\alpha$-amylase by the fungus (Singh et al. 1989). Furthermore, the ability of A. flavus to grow from the endosperm of maize kernels to the embryo appears to require $\alpha$-amylase activity (Fakhoury and

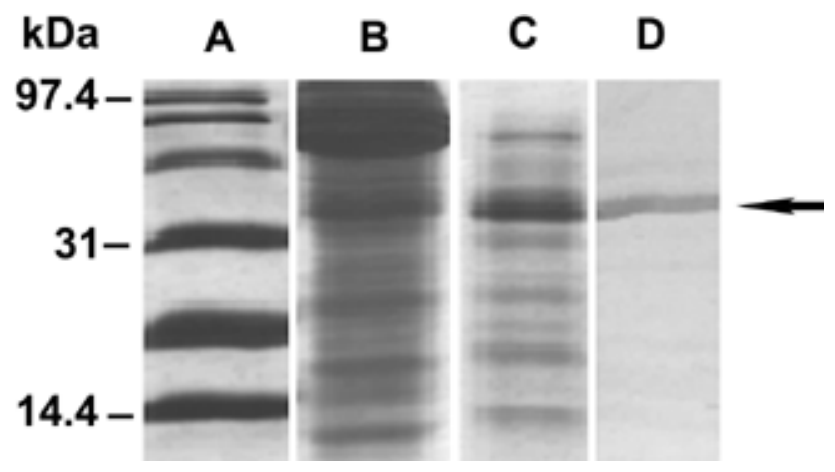

Fig. 1. Sodium dodecyl sulfate-polyacrylamide gel electrophoresis of protein fractions obtained from various steps in $\alpha$-amylase inhibitor from Lablab purpureus (AILP) purification. A, Protein molecular markers. B, Total protein extract form seeds $(5 \mu \mathrm{g})$. C, Protein eluted from chitin column $(1 \mu \mathrm{g})$. D, Fraction from fast protein liquid chromatography containing $1 \mu \mathrm{g}$ of AILP. Gel was stained with $0.025 \%$ Coomassie brilliant blue. 
Woloshuk 1999). Evidence suggesting that inhibitors of $\alpha$ amylases contribute to resistance to fungal pathogens only has been shown recently with the discovery of the 14-kDa trypsin- $\alpha$-amylase inhibitor protein in A. flavus-resistant maize (Chen et al. 1999b). Also, many insect pests feeding on plants require $\alpha$-amylases for normal growth and development (Powers 1977), and inhibitors found in several plant species are part of the defense arsenal against insects (Gatehouse et al. 1986; Powers 1977). In wheat, four families of inhibitors of insect $\alpha$-amylases have been isolated (Feng et al. 1996). Inhibitors also have been isolated from common bean (Phaseolus vulgaris) and maize kernels (Blanco-Labra et al. 1995; Chen et al. 1999b; Powers and Culbertson 1982). Although none of the 30 inhibitors of insect and mammalian $\alpha$-amylases are reported to affect fungal $\alpha$-amylases, parallels can be made between these inhibitors and AILP.

The first indication that $\alpha$-amylase inhibitors may have a role in plant resistance was their specificity. For example, $\alpha$ amylase inhibitors $\alpha \mathrm{AI}-1$ and $\alpha \mathrm{AI}-2$ are two isoforms isolated from different accessions of common bean. $\alpha$ AI- 1 inhibits the $\alpha$-amylases of cowpea weevil (Callosobruchus maculatus) and azuki bean weevil (Callostrobruchus chinensis) but does not inhibit the $\alpha$-amylase of the Mexican weevil (Zabrotes subfasciatus). In contrast, $\alpha \mathrm{AI}-2$ inhibits $Z$. subfasciatus $\alpha$ amylase but not $\alpha$-amylases from $C$. maculatus and $C$. chinensis (DeSa et al. 1997). This specificity is hypothesized to have evolved by coadaptation of plants and their pests. Furthermore, $\alpha$-amylase inhibitors do not affect endogenous plant $\alpha$-amylases (Gatehouse et al. 1986; Silano et al. 1975). Fungal $\alpha$-amylase inhibitors also exhibit specificity. The 14$\mathrm{kDa}$ trypsin- $\alpha$-amylase inhibitor from maize inhibited the $\alpha$ amylase from A. flavus but not the enzyme from porcine pancreas (Fakhoury and Woloshuk 1999). AILP inhibited enzymes from $A$. flavus, $H$. victoriae, and $M$. grisea much greater than the enzymes from $F$. verticillioides and $F$. graminearum. AILP did not effectively inhibit the $\alpha$-amylases from maize, human saliva, and porcine pancreas. Whether AILP and the $14-\mathrm{kDa}$ trypsin- $\alpha$-amylase inhibitor affect insect $\alpha$-amylases remains to be determined.

Several $\alpha$-amylase inhibitors can be described as "bifunctional proteins." Inhibitors from maize (Blanco-Labra et al. 1995; Chen et al. 1999a), barley (Barber et al. 1986), and tepary bean (Campos et al. 1997) also inhibit trypsin. The two

$\begin{array}{ll}\text { AILP (1) } & \text { ANLISFTQKRFDEQNLIGQGDA } \\ \text { PHY : } & \text { ANDISFNFQRFNETNLILQGDA } \\ \text { AIL: } & \text { ANDIFFDIDRFNETNLILQGDA } \\ & \\ \text { AILP (2) } & \text { ATTADGLAFALVPVGAQP--R } \\ \text { PHY: } & \text { AGPADGLAFALVPVGSKPKDR } \\ \text { AIL: } & \text { VTSGYGLAFALVPVDSQPKRK } \\ & \\ \text { AILP (3) } & \text { NA-WDPETYHIGIDVNNIKSI } \\ \text { PHY: } & \text { NRDWDPRERHIGIDVNSIKSI } \\ \text { AIL: } & \text { AVVFDTFSNRIGIDVNSVQSI }\end{array}$

Fig. 2. Comparison of the amino acid sequence of $\alpha$-amylase inhibitor from Lablab purpureus (AILP) with PHY, a phytohemagglutinin precursor from Phaseolus acutifolius, and AIL, an $\alpha$-amylase inhibitor-like protein from Phaseolus lunatus. AILP (1): N terminus; AILP (2) and (3): tryptic fragments. $\alpha$-amylase-trypsin inhibitors from maize appear to have different specificity to fungal $\alpha$-amylases. The $29.6-\mathrm{kDa}$ protein isolated by Blanco-Labra et al. (1995) inhibited $\alpha$-amylases from three insect species but not those from human saliva, porcine pancreas, Aspergillus oryzae, wheat, rye, barley, and sorghum. In contrast, the $14-\mathrm{kDa}$ inhibitor isolated by Chen et al. (1999b) inhibited the $\alpha$-amylase from A. flavus, a close relative of A. oryzae (Fakhoury and Woloshuk 1999).

Amino acid sequence analysis of AILP revealed a similarity to the lectin-arcelin- $\alpha$-amylase inhibitor family described in P. vulgaris (Mirkov et al. 1994). Members of this family have 45 to $85 \%$ amino acid sequence identity and are encoded by genes that are linked. The genes are believed to have originated through duplication and divergence of an ancestral gene (Mirkov et al. 1994). Members that are lectins agglutinate red blood cells, whereas the arcelins only agglutinate blood cells pretreated with pronase. Those members that inhibit $\alpha$ amylases lack lectin activity and require proteolytic process-
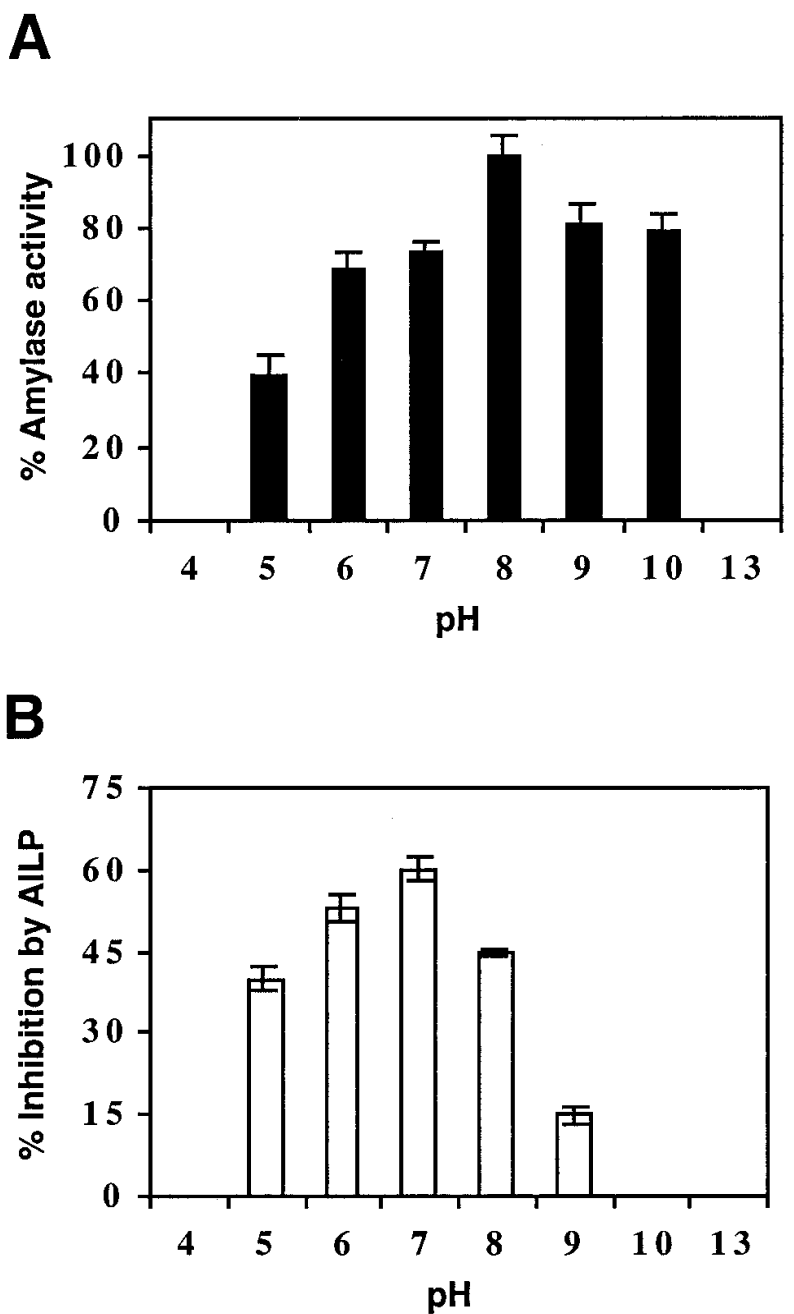

Fig. 3. Effect of $\mathrm{pH}$ on $\alpha$-amylase (closed box) and $\alpha$-amylase inhibitor from Lablab purpureus (AILP) activity (open box). The percent of $\alpha$ amylase activity was calculated relative to the activity at $\mathrm{pH}$ 8.0. AILP activity was calculated relative to the $\alpha$-amylase activity in the presence of AILP compared with the activity of $\alpha$-amylase in the absence of the inhibitor at each $\mathrm{pH}$. Brackets indicate standard deviation from five replicates. 
ing at an asparagine residue to form the $\alpha$ and $\beta$ subunits of the active inhibitor (Pueyo et al. 1993). One exception is the $\alpha$-amylase-like inhibitor AIL, which is not processed (FinardiFilho et al. 1996). Insects feeding on legumes apparently are killed as a result of the lectin or $\alpha$-amylase inhibitor activity of these proteins, but the mode of action of the arcelins remains unknown. Mirkov et al. (1994) further classified members of the lectin-arcelin- $\alpha$-amylase inhibitor family on the basis of the amino acid sequences. Analysis of amino acid alignments revealed three gaps, G1, G2, and G3, in the $\alpha$ amylase inhibitor sequences compared with the lectins. Arcelins contain one gap at G3. The $\alpha$-amylase-like inhibitor AIL contains gaps at G1 and G3, which suggests that this protein is an evolutionary intermediate (Finardi-Filho et al. 1996). AILP from L. purpureus may represent another variant in this family of proteins. Of the three AILP peptides sequenced, peptide 3 contained an amino acid stretch (NAWDETYH) within the G3 gap region that is similar to that found in lectins. With polymerase chain reaction primers derived from peptides 1 and 2, we isolated a product from $L$. purpureus spanning the G1 gap region (A. M. Fakhoury and C. P. Woloshuk, unpublished). Translation of the DNA sequence indicates no gap in the amino acid sequence when aligned with lectins, and the sequence contains a conserved aspartic acid residue essential for carbohydrate binding in lectins (Mirkov et al. 1994). A conserved asparagine believed to be involved in binding to carbohydrates also is present in the peptide 3 sequence of AILP. These data suggest that AILP is a new member of the lectin-arcelin- $\alpha$-amylase inhibitor family, having lectin-like activity and sequence similarity, with $\alpha$-amylase inhibitory activity specific to fungal $\alpha$ amylases. Further characterization of AILP may divulge new physiological activities of the bean lectin-arcelin- $\alpha$-amylase family, thus revealing other roles of this family in plantmicrobe interactions.
Our data indicate that AILP is a competitive inhibitor of $\alpha$ amylase, suggesting that the interaction of AILP with $\alpha$ amylase blocks access of the substrate to the active site of the enzyme. Such a mechanism has been suggested from X-ray studies of porcine pancreas $\alpha$-amylase complexed with $\alpha \mathrm{AI}-1$ from P. vulgaris (Bompard-Gilles et al. 1996). Furthermore, modeling studies by Le-Berre-Anton et al. (2000) suggest that proteolytic processing of $\alpha \mathrm{AI}-1$ allows loops on the two subunits to enter the cleft containing the active site of the enzyme. When not processed, the loops fail to fit into this site. These authors also conclude that the three-dimensional structure of $\alpha$-amylase may contribute to the specificity of the $\alpha$ amylase inhibitor. It appears that AILP is not processed to an active form, which may account for the lack of activity against porcine pancreas $\alpha$-amylase. Inhibition of fungal $\alpha$-amylases may indicate important structural differences among $\alpha$ amylases, which need further study.

AILP inhibited the growth of A. flavus, even when grown on sugar-rich potato dextrose broth (PDB) medium, indicating that the growth-inhibiting activity of AILP is independent of its $\alpha$-amylase inhibitory activity. Several plant lectins are reported to have antifungal activity. Urtica dioica agglutinin (nettle lectin) has strong antifungal properties against several chitin-producing fungi (Broekaert et al. 1989). Hevein, a lectin from the rubber tree Hevea brasiliensis, inhibited the growth of Botrytis cinerea, Fusarium oxysporum, and Pyrenophora tritici in vitro (Vanparijs et al. 1991). A lectin from potato tubers also was reported to inhibit conidial germination and to alter germ tubes of $F$. oxysporum (Gozia et al. 1993). More recently, an antifungal lectin was isolated from Gastrodia elata (Xu et al. 1998). The protein inhibited the hyphal growth of $B$. cinerea and Rhizoctonia solani. We suspect that the lectin nature of AILP and its affinity for chitin may be responsible for its inhibition of fungal growth. AILP may inhibit fungal growth by cross-linking chitin, thereby

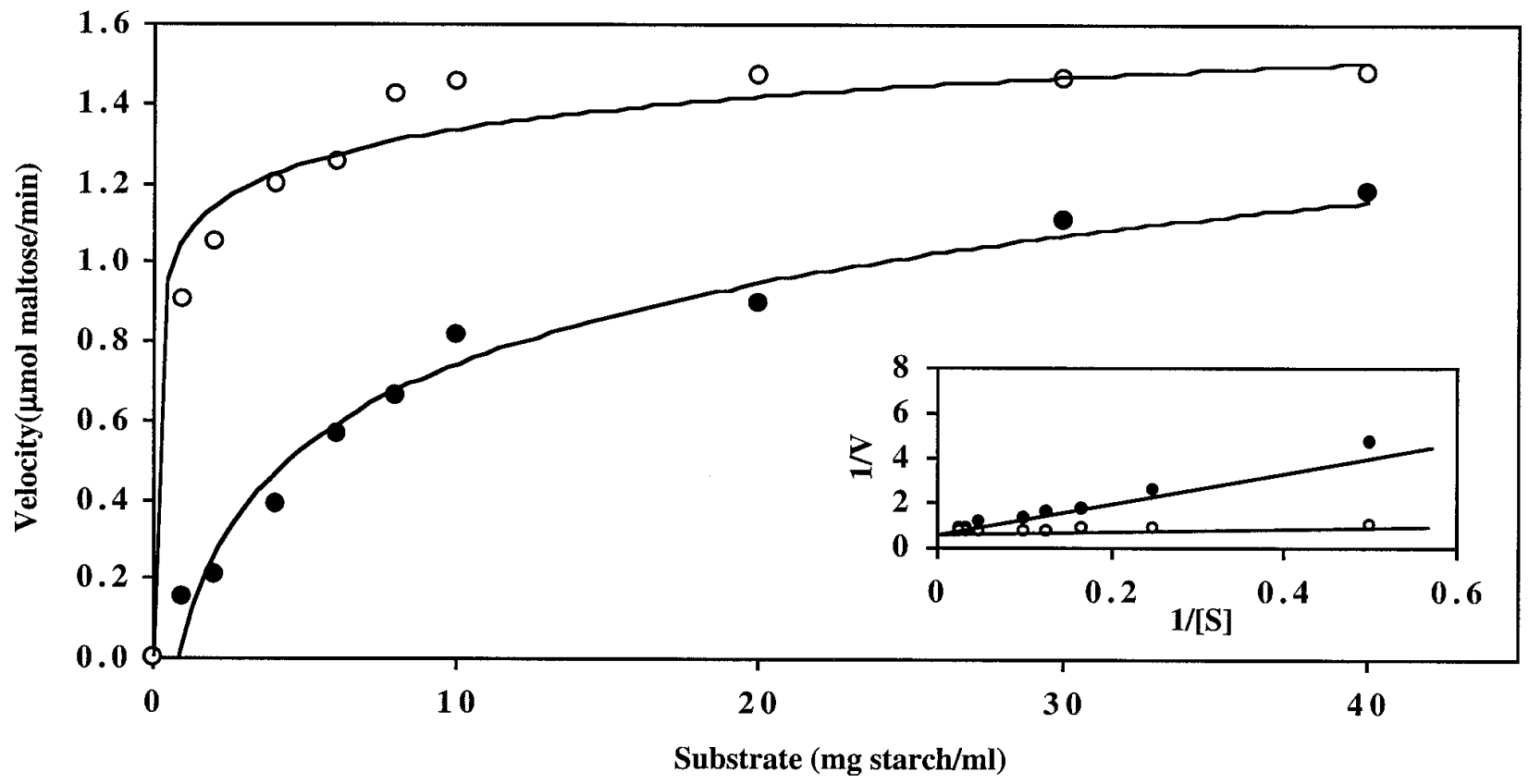

Fig. 4. Effect of starch concentration on $\alpha$-amylase activity with (closed circles) and without $\alpha$-amylase inhibitor from Lablab purpureus (open circles). 
preventing cell expansion of the tip of growing hyphae, as hypothesized for other lectins by Broekaert et al. (1989).

The expression of $\alpha$-amylase inhibitors and lectins in plants has proven successful in increasing resistance to insects. Transgenic peas (Pisum sativum) expressing the $\alpha$-amylase inhibitor $\alpha$ AI were resistant to several species of bruchids (Schroeder et al. 1994; Shade et al. 1994). Moreover, expression in tobacco of a lectin gene from snowdrops (Galanthus nivalis) enhanced resistance to the peach potato aphid (Myzus persicae) (Vaughan and Boulter 1999). Expressing AILP in maize may prove to be useful as a strategy to control A. flavus infections in maize, especially because the protein has little effect on $\alpha$-amylases from animal or plant origins. AILP in endosperm tissue could slow fungal growth as well as prevent the degradation of a major component, starch, which is needed for aflatoxin production. If the fungus reaches embryo tissue where the degradation of lipids can fuel aflatoxin production, growth and aflatoxin production could be effectively inhibited by the antifungal properties of AILP.

\section{MATERIALS AND METHODS}

\section{Fungal strains.}

H. victoriae strain HV033 was obtained from L. D. Dunkle (Purdue University), F. verticillioides strain A0149 was provided by A. Desjardins (USDA-ARS, NRRC, Peoria, IL, U.S.A.), F. graminearum was provided by G. Shaner (Purdue University), C. graminicola was obtained from R. Hanau (Purdue University), and M. grisea strain Guy11 was obtained from J.-R. Xu (Purdue University). A. flavus strain NRRL 3357 was obtained from USDA-ARS, NRRC. A. flavus strain 33 previously was isolated in this laboratory (Fakhoury and Woloshuk 1999). Fungal cultures were maintained on potato dextrose agar (Difco, Detroit, MI, U.S.A.).

\section{Partial purification of $\alpha$-amylases.}

The $\alpha$-amylases from $B$. subtilis, porcine pancreas, and human saliva were purchased from Sigma Chemical (St. Louis, MO, U.S.A.). Fungal $\alpha$-amylases were purified partially from cultures grown in $200 \mathrm{ml}$ of starch medium $\left(35 \mathrm{mM} \mathrm{NaNO}_{3}, 6\right.$ $\mathrm{mM} \mathrm{K}_{2} \mathrm{HPO}_{4}, 4 \mathrm{mM} \mathrm{MgSO}$, $7 \mathrm{mM} \mathrm{KCl}, 10 \mathrm{mM}$ leucine, $2 \%$ soluble starch, and $0.07 \mathrm{mM} \mathrm{FeSO}_{4}$ ) at $28^{\circ} \mathrm{C}$, with shaking at $150 \mathrm{rpm}$. After 8 days of incubation, cultures were centrifuged at $5,000 \mathrm{~g}$ for $10 \mathrm{~min}$, supernatants were filtered through Miracloth (Calbiochem-Behring, San Diego, CA, U.S.A.), and proteins were precipitated with ammonium sulfate $(85 \%$ saturation). Proteins were pelleted by centrifugation at $12,000 \mathrm{~g}$ for $10 \mathrm{~min}$, dissolved in $0.1 \mathrm{M}$ potassium phosphate buffer, $\mathrm{pH}$ 6.5, and dialyzed against the same buffer for $20 \mathrm{~h}$. To test for the contamination of glucoamylase and $\beta$-glucosidase, 10 $\mu \mathrm{l}$ of partially purified $\alpha$-amylase was added to $1 \mathrm{ml}$ of $p$ -

Table 2. Effect of $\alpha$-amylase inhibitor from Lablab purpureus (AILP) on Aspergillus flavus ${ }^{\mathrm{a}}$

\begin{tabular}{llrc}
\hline & Control & AILP & Boiled AILP \\
\hline Conidial germination $(\%)$ & $84 \pm 5^{\mathrm{b}}$ & $14 \pm 4$ & $81 \pm 5$ \\
Hyphal length $(\mu \mathrm{m})$ & $24 \pm 1$ & $8 \pm 1$ & $23 \pm 2$ \\
\hline
\end{tabular}

${ }^{a}$ Eight-thousand conidia were incubated $24 \mathrm{~h}$ with 280 pmoles of AILP in $60 \mu \mathrm{l}$ of potato dextrose broth.

${ }^{\mathrm{b}}$ Data are the mean of three replicates \pm standard deviation. nitrophenyl- $\alpha$-D-glucopyranoside or $p$-nitrophenyl- $\beta$-D-glucopyranoside (Sigma), respectively. The enzyme reactions were incubated at $37^{\circ} \mathrm{C}$ for up to $1 \mathrm{~h}$. Reactions were stopped with $100 \mu \mathrm{l}$ of $1 \mathrm{M} \mathrm{NaOH}$ and the production of $p$-nitrophenol was measured at $420 \mathrm{~nm}$ with a Beckman DU-70 spectrophotometer (Fullerton, CA, U.S.A.) (Sun and Hensom 1990). If these enzymes were present, the protein fractions were applied to a $20 \times 1.5 \mathrm{~cm}$ DEAE-Sephadex A50 column (Amersham Pharmacia Biotech, Uppsala, Sweden) and bound $\alpha$-amylase was eluted with a linear salt gradient from 0 to $0.5 \mathrm{M} \mathrm{NaCl}$ in $50 \mathrm{mM}$ potassium phosphate buffer $(\mathrm{pH}$ 6.5). All $\alpha$-amylase fractions used in this study were free of detectable glucoamylase and $\beta$-glucosidase. Fractions containing $\alpha$-amylase were pooled and frozen at $-20^{\circ} \mathrm{C}$.

Maize $\alpha$-amylase was obtained by homogenizing germinated kernels with a coffee grinder and extracting with buffer $\left(5 \% \mathrm{NaCl}\right.$ in $0.01 \mathrm{M}$ Tris-[HCl], $\mathrm{pH} \mathrm{7.2)}$ for $2 \mathrm{~h}$ at $4^{\circ} \mathrm{C}$. The extract was filtered through cheesecloth, and the filtrate was centrifuged at $10,000 \mathrm{~g}$ for $1 \mathrm{~h}$ at $4^{\circ} \mathrm{C}$. Proteins in the supernatant were precipitated overnight with ammonium sulfate ( $85 \%$ saturation) at $4^{\circ} \mathrm{C}$. After centrifugation at $10,000 \times g$ for $1 \mathrm{~h}$, the pellet was dissolved in water, dialyzed overnight against water, and then concentrated by lyophilization. The dried proteins were dissolved in $50 \mathrm{mM}$ potassium phosphate buffer, pH 6.5, and applied to a $20 \times 1.5 \mathrm{~cm}$ DEAE-Sephadex A50. Bound $\alpha$-amylase was eluted with a linear gradient of 0 to $0.5 \mathrm{M} \mathrm{NaCl}$ in $50 \mathrm{mM}$ potassium phosphate buffer, $\mathrm{pH} 6.5$. Fractions containing $\alpha$-amylase activity were pooled and frozen at $-20^{\circ} \mathrm{C}$.

\section{$\alpha$-Amylase and $\alpha$-amylase inhibitor assays.}

When starch was used as the substrate for $\alpha$-amylase, enzyme activity was determined by measuring the release of reducing sugars (Chaplin 1994). One unit of $\alpha$-amylase produced the equivalent of $1 \mathrm{mg}$ of maltose from starch in $3 \mathrm{~min}$ at $\mathrm{pH} 6.9$ and $20^{\circ} \mathrm{C}$. Alternatively, $1 \mathrm{mM} p$-nitrophenyl- $\alpha$-Dmaltoside (Sigma) in PNC buffer (0.05 M potassium phosphate buffer, $\mathrm{pH} 6.9 ; 0.25 \mathrm{M} \mathrm{NaCl}$; and $1 \mathrm{mM} \mathrm{CaCl}_{2}$ ) was used as a substrate for $\alpha$-amylase. Release of $p$-nitrophenol at $37^{\circ} \mathrm{C}$ was monitored continuously at $400 \mathrm{~nm}$ with a Beckman DU-70 spectrophotometer.

To measure $\alpha$-amylase inhibitor activity, protein solutions were mixed with $\alpha$-amylase in a volume of $0.1 \mathrm{ml}$ and incubated at $37^{\circ} \mathrm{C}$ for $30 \mathrm{~min}$ prior to the addition of $0.1 \mathrm{ml}$ of $0.5 \%$ soluble starch or $0.9 \mathrm{ml}$ of $1 \mathrm{mM} p$-nitrophenyl- $\alpha$-Dmaltoside. After $10 \mathrm{~min}$ of incubation with the substrates at

Table 3. Effect of $\alpha$-amylase inhibitor from Lablab purpureus (AILP) on various $\alpha$-amylases ${ }^{\mathrm{a}}$

\begin{tabular}{lc}
\hline Source of $\alpha$-amylase & Inhibition (\%) \\
\hline Aspergillus flavus & 68 \\
Colletotrichum graminicola & 30 \\
Fusarium graminearum & 18 \\
Fusarium verticillioides & 15 \\
Helminthosporium victoriae & 72 \\
Magnaporthe grisea & 77 \\
Bacillus subtilis & 41 \\
Maize & 5 \\
Human saliva & 11 \\
Porcine pancreas & 6 \\
\hline
\end{tabular}

${ }^{\mathrm{a}}$ Ten units of the $\alpha$-amylases were incubated with and without 45 pmoles of AILP. 
$37^{\circ} \mathrm{C}$, the amount of reducing sugars or $p$-nitrophenol released was determined. One unit of $\alpha$-amylase inhibitor reduced $1 \mathrm{U}$ of $\alpha$-amylase by $50 \%$ under the conditions of the assay.

\section{Effect of pH.}

$\alpha$-Amylase (0.03 units) was incubated at various $\mathrm{pHs}$, with and without 45 pmoles of AILP, for $30 \mathrm{~min}$ at $37^{\circ} \mathrm{C}$ prior to adding $0.5 \%$ starch. The following buffers were used to attain the different pHs: $0.1 \mathrm{M}$ Tris- $(\mathrm{HCl}), \mathrm{pH} 8.0 ; 0.1 \mathrm{M}$ sodium acetate, $\mathrm{pH} 3.2,4.0$, and 5.0; and $0.1 \mathrm{M}$ potassium phosphate buffer, $\mathrm{pH}$ 6.0. Sodium hydroxide $(0.1 \mathrm{M})$ was used to obtain a $\mathrm{pH}$ of 13 and $0.1 \mathrm{M}$ glycine- $\mathrm{NaOH}$ for $\mathrm{pH} 9.0$ and 10.0 . Percent inhibition was calculated by comparing the $\alpha$-amylase activity in the presence of AILP with activity in the absence of the inhibitor at a given $\mathrm{pH}$.

\section{Purification of AILP from L. purpureus.}

L. purpureus seeds were obtained from the Thomas Jefferson Center for Historic Plants (Charlottesville, VA, U.S.A.). Five grams of dry seeds were ground to a fine powder with a coffee bean grinder and extracted with $200 \mathrm{ml}$ of $0.01 \mathrm{M}$ Tris$(\mathrm{HCl}), \mathrm{pH} 7.2$, with $5 \% \mathrm{NaCl}$, for $2 \mathrm{~h}$ at room temperature. The extract was filtered through cheesecloth and the filtrate centrifuged at $10,000 \mathrm{~g}$ for $1 \mathrm{~h}$ at $4^{\circ} \mathrm{C}$. Proteins in the supernatant were precipitated with ammonium sulfate $(60 \%$ saturation) for $12 \mathrm{~h}$ at $4^{\circ} \mathrm{C}$ and then centrifuged at $10,000 \mathrm{~g}$ for $1 \mathrm{~h}$. The pellet was dissolved in water, dialyzed extensively against water, and lyophilized. After dissolving the proteins in $0.1 \mathrm{M}$ Tris-( $\mathrm{HCl}), \mathrm{pH} 6.8,40 \mathrm{mg}$ of protein was applied to a chitin, crab shell column (Sigma; $15 \times 1 \mathrm{~cm}$ ) equilibrated with the same buffer. Bound proteins were eluted with $0.05 \mathrm{M} \mathrm{HCl}$, dialyzed overnight against water at $4^{\circ} \mathrm{C}$, and lyophilized. These proteins were dissolved subsequently in $20 \mathrm{mM}$ bis (2hydroxyethyl) immino-tris (hydroxymethyl) methane (BisTris) buffer, $\mathrm{pH} 6.4$, and loaded onto a fast protein liquid chromatography-mono Q column (HR5/5; Amersham Pharmacia Biotech). Bound proteins were eluted with a gradient of 0 to $1 \mathrm{M} \mathrm{NaCl}$ in $20 \mathrm{mM}$ Bis-Tris buffer, $\mathrm{pH}$ 6.4. Fractions containing $\alpha$-amylase inhibitory activity were pooled and stored at $-20^{\circ} \mathrm{C}$.

\section{Protein analysis.}

Protein concentrations were determined by the method of Bradford (1976). Proteins were resolved by $15 \%$ SDS-PAGE, as described by Laemmli (1970), and the gels were stained with $0.025 \%$ Coomassie brilliant blue (Sigma). For amino acid analysis, AILP was electroblotted after $12 \%$ SDS-PAGE to a polyvinylidene difluoride membrane, as described by Chen et al. (1997). Amino acid sequencing of the $\mathrm{N}$ terminus and tryptic fragments was performed by the Sequencing Facility in the Department of Biochemistry at Purdue University. Database searches were done via BLAST (National Center for Biotechnology Information, Bethesda, MD, U.S.A.).

\section{SDS-PAGE recovery of AILP activity.}

After separation by $15 \%$ SDS-PAGE and staining with Coomassie blue, the purified AILP band was excised and eluted with a Bio-Rad Electro-Eluter model 422 (Richmond, CA, U.S.A.), following the manufacturer's instructions. The eluted protein was precipitated by the addition of 1 volume of cold ethanol and incubation in a dry ice bath for $30 \mathrm{~min}$. After centrifugation for $10 \mathrm{~min}$ at $12,000 \mathrm{~g}$, the pellet was lyophilized, then dissolved in $20 \mu \mathrm{l}$ of $6 \mathrm{M}$ guanidine- $\mathrm{HCl}$ prepared in a dilution buffer (0.05 M Tris-[HCl], $\mathrm{pH} 7.9 ; 20 \%$ glycerol; $0.1 \mathrm{mg}$ of bovine serum albumin per $\mathrm{ml} ; 0.15 \mathrm{M} \mathrm{NaCl} ; 1 \mathrm{mM}$ dithiothreitol; and $0.1 \mathrm{mM}$ EDTA). After incubation at room temperature for $20 \mathrm{~min}$, the mixture was diluted 50-fold with dilution buffer and incubated for $12 \mathrm{~h}$ at room temperature. The protein was then concentrated by lyophilization and analyzed for $\alpha$-amylase inhibitory activity.

\section{Lectin assay.}

Human blood group O (Sigma), rabbit, bovine, and horse red blood cells (Lampshire Biological, Pipersville, PA, U.S.A.), $0.2 \mathrm{ml}$, were suspended in $1.0 \mathrm{ml}$ of buffer $(50 \mathrm{mM}$ $\left.\mathrm{KH}_{2} \mathrm{PO}_{4} ; 150 \mathrm{mM} \mathrm{NaCl}, \mathrm{pH} 7.5\right)$ and treated with $1.5 \mathrm{U}$ of papain (Sigma) for $30 \mathrm{~min}$ at $37^{\circ} \mathrm{C}$. Agglutination of the blood cells as a measure of lectin activity was determined by adding $4 \mu \mathrm{g}$ of AILP to papain-treated cells and incubating for $30 \mathrm{~min}$ at $37^{\circ} \mathrm{C}$. Lectin from $P$. vulgaris (Sigma) was used as a positive control.

\section{Trypsin inhibitor assay.}

Trypsin from $10 \mu \mathrm{g}$ of porcine pancreas (Sigma) was mixed with $\quad 0.2 \quad \mathrm{mM} \quad \mathrm{N}$ - $\alpha$-benzoyl-DL-arginine- $p$-nitroanilide (BAPNA; Sigma) in 0.1 M Tris- $(\mathrm{HCl})$ buffer, $\mathrm{pH} 8.2$, and incubated at $25^{\circ} \mathrm{C}$. Trypsin activity was monitored at $412 \mathrm{~nm}$ with a Beckman DU40 spectrophotometer. To test AILP for trypsin-inhibitory activity, AILP was incubated with the tryp$\sin$ at $25^{\circ} \mathrm{C}$ for $10 \mathrm{~min}$ before the substrate was added. Soybean trypsin inhibitor (Sigma) was used as a positive control.

\section{Fungal growth assay.}

PDB (60 $\mu \mathrm{l}$; Difco), containing $8 \times 10^{3}$ conidia of $A$. flavus strain 3357 was placed on a sterile depression slide and incubated in a humid chamber at room temperature for $24 \mathrm{~h}$. AILP ( 280 pmoles in $40 \mu \mathrm{l}$ ) was added to the medium to test for inhibition of conidial germination and hyphal growth. Germination data were collected from three replicates comprising 250 conidia each. Hyphal growth data represent three replicates, each comprising a measurement of 250 hyphae.

\section{ACKNOWLEDGMENTS}

We thank L. Murdock and D. Shade for allowing us to screen their seed extract collection. Support for this research was provided by USDA Cooperative Agreement 58-6435-8-118. This report constitutes Journal Publication 16443 of the Purdue University Agriculture Research Program.

\section{LITERATURE CITED}

Barber, D., Sanchezmonge, R., Mendez, E., Lazaro, A., Garciaolmedo, F., and Salcedo, G. 1986. New $\alpha$-amylase and trypsin-inhibitors among the CM-proteins of barley (Hordeum vulgare). Biochim. Biophys. Acta 869:115-118.

Blanco-Labra, A., Chagolla-Lopez, A., Martinez-Gallardo, N., and Valdes-Rodriguez, S. 1995. Further characterization of the 12-kDa protease $\alpha$-amylase inhibitor present in maize seeds. J. Food Biochem. 19:27-41.

Bompard-Gilles, C., Rousseau, P., Rouge, P., and Payan, F. 1996. Substrate mimicry in the active center of a mammalian $\alpha$-amylase: Structure analysis of an enzyme-inhibitor complex. Structure 102:14411452.

Bradford, M. M. 1976. A rapid and sensitive method for the quantitation 
of microgram quantities of protein utilizing the principle of proteindye binding. Anal. Biochem. 72:248-254.

Broekaert, W. F., Vanparijs, J., Leyns, F., Joos, H., and Peumans, W. J. 1989. A chitin-binding lectin from stinging nettle rhizomes with antifungal properties. Science 245:1100-1102.

Campbell, K. W., and White, D. G. 1995a. Evaluation of corn genotypes for resistance to Aspergillus ear rot, kernel infection, and aflatoxin production. Plant Dis. 79:1039-1045.

Campbell, K. W., and White, D. G. 1995b. Inheritance of resistance to Aspergillus ear rot and aflatoxin in corn genotypes. Phytopathology 85:886-896.

Campos, J. E., Martinez-Gallardo, N., Mendiola-Olaya, E., and BlancoLabra, A. 1997. Purification and partial characterization of a proteinase inhibitor from tepary bean (Phaseolus acutifolius) seeds. J. Food Biochem. 21:203-218.

Chaplin, M. 1994. Monosaccharides. Pages 1-41 in: Carbohydrate Analysis: A Practical Approach. M. F. Chaplin and J. F. Kennedy, eds. Oxford University Press, Oxford, U.K.

Chen, Z. Y., Lavigne, L. L., Mason, C. B., and Moroney, J. V. 1997. Cloning and overexpression of two cDNAs encoding the low $\mathrm{CO}_{2}$ inducible chloroplast envelope protein LIP-36 from Chlamydomonas reinhardtii. Plant Physiol. 114:265-273.

Chen, Z.-Y., Brown, R. L., Lax, A. R., Guo, B. Z., Cleveland, T. E., and Russin, J. S. 1998. Resistance to Aspergillus flavus in corn kernels is associated with a 14-kDa protein. Phytopathology 88:276-281.

Chen, Z.-Y., Brown, R. L., Lax, A. R., Cleveland, T. E., and Russin, J. S. 1999a. Inhibition of plant-pathogenic fungi by a corn trypsin inhibitor overexpressed in Escherichia coli. Appl. Environ. Microbiol. 65:1320-1324.

Chen, Z.-Y., Brown, R. L., Russin, J. S, Lax, A. R., and Cleveland, T. E. 1999b. A corn trypsin inhibitor with antifungal activity inhibits Aspergillus flavus $\alpha$-amylase. Phytopathology 89:902-907.

DeSa, M. F. G., Mirkov, T. E., Ishimoto, M., Colucci, G., Bateman, K. S., and Chrispeels, M. J. 1997. Molecular characterization of a bean $\alpha$-amylase inhibitor that inhibits the alpha-amylase of the Mexican bean weevil Zabrotes subfasciatus. Planta 203:295-303.

Dohroo, N. P., Bhardwaj, S. S., and Shyram, K. R. 1987. Amylase and invertase activity as influenced by Pythium pleroticum causing rhizome rot of ginger. Plant Dis. Res. 2:106-107.

Fakhoury, A. M., and Woloshuk, C. P. 1999. Amy1, the $\alpha$-amylase gene of Aspergillus flavus: Involvement in aflatoxin biosynthesis in maize kernels. Phytopathology 89:908-914.

Feng, G. H., Richardson, M., Chen, M. S., Kramer, K. J., Morgan, T. D., and Reeck, G. R. 1996. $\alpha$-Amylase inhibitors from wheat: Amino acid sequences and patterns of inhibition of insect and human alphaamylases. Insect Biochem. Mol. Biol. 26:419-426.

Finardi-Filho, F., Mirkov, T. E., and Chrispeels, M. 1996. A putative precursor protein in the evolution of the bean $\alpha$-amylase inhibitor. Phytochemistry 43:57-62.

Gatehouse, A. M. R., Fenton, K. A., Jepson, I., and Pavey, D. J. 1986. The effects of $\alpha$-amylase inhibitors on insect storage pests: Inhibition of $\alpha$-amylase in vitro and effects on development in vivo. J. Sci. Food Agric. 37:727-734.

Gozia, O., Ciopraga, J., Bentia, T., Lungu, M., Zamfirescu, I., Tudor, R., Roseanu, A., and Nitu, F. 1993. Antifungal properties of lectin and new chitinases from potato tubers. C. R. Acad. Sci. Ser. III Sci. Vie 316:788-792.

Guo, B. Z., Russin, J. S., Cleveland, T. E., Brown, R. L., and Widstrom, N. W. 1995. Wax and cutin layers in maize kernels associated with resistance to aflatoxin production by Aspergillus flavus. J. Food Prot. 58:296-300.

Guo, B. Z., Chen, Z.-Y., Brown, R. L., Lax, A. R., Cleveland, T. E.,
Russin, J. S., Mehta, A. D., Selitrennikoff, C. P., and Widstrom, N. W. 1997. Germination induces accumulation of specific proteins and antifungal activities in corn kernels. Phytopathology 87:1174-1178.

Guo, B. Z., Brown, R. L., Lax, A. R., Cleveland, T. E., Russin, J. S., and Widstrom, N. W. 1998. Protein profiles and antifungal activities of kernel extracts from corn genotypes resistant and susceptible to Aspergillus flavus. J. Food Prot. 61:98-102.

Huang, Z. Y., White, D. G., and Payne, G. A. 1997. Corn seed proteins inhibitory to Aspergillus flavus and aflatoxin biosynthesis. Phytopathology 87:622-627.

Laemmli, U. 1970. Cleavage of structural proteins during the assembly of the head of bacteriophage T4. Nature 227:680-685.

Le Berre-Anton, V., Nahoum, V., Payan, F., and Rouge, P. 2000. Molecular basis for the specific binding of different $\alpha$-amylase inhibitors from Phaseolus vulgaris seeds to the active site of $\alpha$-amylase. Plant Physiol. Biochem. 38:657-665.

Mirkov, T. E., Wahlstrom, J. M., Hagiwara, K., Finardifilho, F., Kjemtrup, S., and Chrispeels, M. J. 1994. Evolutionary relationships among proteins in the phytohemagglutinin-arcelin- $\alpha$-amylase inhibitor family of the common bean and its relatives. Plant Mol. Biol. 26:1103-1113.

Powers, J. 1977. Purification and some physical and chemical properties of red kidney bean (Phaseolus vulgaris) $\alpha$-amylase inhibitor. J. Food Biochem. 1:217-238.

Powers, J. R., and Culbertson, J. D. 1982. In vitro effect of bean amylase inhibitor on insect amylases. J. Food Prot. 45:655-657.

Pueyo, J. J., Hunt, D. C., and Chrispeels, M. J. 1993. Activation of bean (Phaseolus vulgaris) $\alpha$-amylase inhibitor requires proteolytic processing of the proprotein. Plant Physiol. 101:1341-1348.

Russin, J. S., Guo, B. Z., Tubajika, K. M., Brown, R. L., Cleveland, T. E., and Widstrom, N. W. 1997. Comparison of kernel wax from corn genotypes resistant or susceptible to Aspergillus flavus. Phytopathology 87:529-533.

Schroeder, H. E., Gollasch, S., Moore, A., Tabe, L. M., Craig, S., Hardie, D. C., Chrispeels, M. J., Spencer, D., and Higgins, T. J. V. 1995. Bean $\alpha$-amylase inhibitor confers resistance to the pea weevil (Bruchus pisorum) in transgenic peas (Pisum sativum L). Plant Physiol. 107:12331239.

Shade, R. E., Schroeder, H. E., Pueyo, J. J., Tabe, L. M., Murdock, L. L., Higgins, T. J. V., and Chrispeels, M. J. 1994. Transgenic pea seeds expressing the $\alpha$-amylase inhibitor of the common bean are resistant to bruchid beetles. Biotechnology 12:793-796.

Silano, V., Furia, M., Gianfreda, L., Mcri, A., Palescandolo, R., Rab, A., Scardi, V., Stella, E., and Valfre, F. 1975. Inhibition of amylases from different origins by albumins from the wheat kernel. Biochim. Biophys. Acta 391:170-178.

Singh, R., Saxena, V. S., and Singh, R. 1989. Pectinolytic, cellulolytic, amylase and protease production by three isolates of Fusarium solani variable in their virulence. Indian J. Mycol. Plant Pathol. 19:22-29.

Sun, Z., and Hensom C. A. 1990. Degradation of native starch granules by barley $\alpha$-glucosidases. Plant Physiol. 94:320-327.

Vanparijs, J., Broekaert, W. F., Goldstein, I. J., and Peumans, W. J. 1991. Hevein-an antifungal protein from rubber-tree (Hevea brasiliensis) latex. Planta 183:258-264.

Vaughan, A. H., and Boulter, D. 1999. Genetic engineering of crop plants for insect resistance. Crop Protect. 18:177-191.

Woloshuk, C. P., Cavaletto, J. R., and Cleveland, T. E. 1997. Inducers of aflatoxin biosynthesis from colonized maize kernels are generated by an amylase activity from Aspergillus flavus. Phytopathology 87:164-169.

Xu, Q., Liu, Y., Wang, X. C., Gu, H. Y., and Chen, Z. L. 1998. Purification and characterization of a novel anti-fungal protein from Gastrodia elata. Plant Physiol. Biochem. 36:899-905. 